\title{
PENYULUHAN GIZI DAN PEMBERIAN TABLET BESI TERHADAP PENGETAHUAN DAN KADAR HEMOGLOBIN SISWI SEKOLAH MENENGAH ATAS NEGERI DI MAMUJU
}

\author{
Ahmady $^{1}$, Hapzah $^{2}$, Dina Mariana ${ }^{3}$ \\ ${ }^{1,3}$ Jurusan Kebidanan Poltekkes Kemenkes Mamuju, \\ ${ }^{2}$ Jurusan Keperawatan Poltekkes Kemenkes Mamuju
}

\begin{abstract}
The prevalence of anemia in adolescent girls junior and senior high school in Mamuju is $27 \%$. This study to determine the effect of nutritional counseling and suplementation iron tablets to knowledge and hemoglobin ( $\mathrm{Hb}$ ) status of senior high school student in West Sulawesi. This type of research is a quasi-experimental design using non- randomized control group pretest-posttest. Samples of the intervention group were 30 students and a control group of 30 students. Student knowledge was measured using questionnaires and hemoglobin concentration using hemoglobinometer. Analysis using Wilcoxon Test, Paired Sample T-Test and Independent T Test. The results showed the results of this study showed no difference in the increase in knowledge after counseling, while the suplementation of iron tablets contained elevated levels of hemoglobin.
\end{abstract}

\section{Keyword: counseling, knowledge, Iron suplementation, Hemoglobin}

\section{PENDAHULUAN}

Anemia merupakan defisiensi gizi mikro yang paling sering ditemukan didunia dan menjadi masalah kesehatan masyarakat pada remaja dan dewasa. Masalah ini terutama menjangkiti para wanita dalam usia reproduktif dan anak-anak dewasa dikawasan tropis dan subtropis. Prevalensi anemia di dunia sangat tinggi, terutama di negara-negara sedang berkembang termasuk Indonesia.

World Bank mengestimasikan bahwa peranan langsung anemia karena defisiensi zat besi pada beban global penyakit adalah 14 disabillity-adjusted life-year per 1000 populasi. Masalah ini membawa efek keseluruhan terbesar dalam hal gangguan kesehatan, kematian premature dan kehilangan pendapatan (Michael J.G, 2008). Anemia defisiensi zat besi di negara berkembang sekitar $80 \%$, dikalangan perempuan India terjadi pada usia reproduksi (15 - 45 tahun ) dari strata sosial ekonomi rendah (Ahmed et.all, 2005). Di Bangalore $39 \%$ dari perempuan yang ditemukan anemia adalah 95\% akibat kekurangan zat besi (Sindhu S, Mangala S, Sherry B, 2013). Prevalensi anemia di Indonesia pada tahun 2013 menurut kelompok umur menunjukkan bahwa anemia pada balita cukup tinggi, yaitu $28,1 \%$ diikuti kelompok umur anak sekolah, remaja sampai dewasa muda yaitu $26,4 \%$ (5 - 14 tahun),
$18,4 \%$ (15-24 tahun ) dan 16,9\% (25-34 tahun) (Riskesdas, 2013).

Prevalensi anemia padaremaja putri usia sekolah SMP dan SMA di Sulawesi Barat adalah sebesar $27 \%$, ditinjau dari tingkat keparahan anemia, $0,5 \%$ tergolong anemia sangat berat (severe), 3\% yang mengalami anemia sedang (moderate), dan $24 \%$ tergolong anemia ringan (Ngatimin dan Rahmawati, 2009).

Masalah anemia ibu hamil yang masih cukup tinggi, dapat disebabkanoleh karena masalah anemia yang telah diderita sejak masih remaja. Oleh karena itu, pencegahan anemia harus dimulai pada awal kehamilan, atau bahkan lebih awal lagi, yaitu pada periode remaja, dengan pertimbangan bahwa kejadian anemia pada remaja putri akan membawa konsekuensi negatif terhadap pertumbuhan, prestasi akademik, angka kesakitan, dan kesehatan reproduksi di masa yang akan datang (Arisman MB, 2008).

Masalah anemia pada remaja pada umumnya disebabkan karena intake zat besi yang rendahdan muncul karena pilihan terhadap makanan yang tidak tepat sehingga terdapat ketidakseimbangan antara konsumsi gizi dengan kecukupan gizi yang dianjurkan. Dilain pihak remaja putri cenderung untuk membatasi asupan makanan karena mereka cenderung ingin memiliki tubuh yang langsing dengan 
pengetahuan yang masih rendah terkait anemia (Abbas. dkk, 2005).

Survei Demografi Dan Kesehatan Reproduksi Remaja Tahun 2012 menunjukkan masih rendahnya tingkat pengetahuan remaja (15 - 24 tahun) terkait anemia, sebanyak $78 \%$ responden pria dan $67 \%$ responden wanita menyebutkan penyebab anemia dengan kategori lainnya dan tidak tahu sama sekali (Survei Demografi Dan Kesehatan Reproduksi Remaja, 2012). Sementara menurut riskesdas 2013 dalam angka menunjukkan semakin tinggi pendidikanterkait pengetahuan, maka semakin besar persentase cakupan konsumsi zat besi (Riskesdas, 2013).

Siswi SMA merupakan bagian dari pada kelompok remaja, dimana proses pertumbuhannya masih terjadi meskipun melambat, sehingga masih perlu mendapat perhatian. Siswi SMA pada umumnya menghabiskan sebagian besar waktunya untuk aktivitas di sekolah, dengan aktivitas yang beragam tentunya akan mempengaruhi pola makan yang teratur. Selain karena keterbatasan intake pangan remaja putri secara normal akan mengalami kehilangan darah melalui menstruasi setiap bulan dan akan meningkatkan kebutuhan zat besi selama growth spurt. Sehinggasiswa dengan beragam aktivitas tersebut akan lebih berisiko menderita Anemia akibat defisiensi zat besi. Kekurangan Zat besi dapat memyebabkan menurunnya konsentrasi dan menurunnya semangat belajar akibatnya akan berdampak pada prestasi belajar dan aktivitas fisik. Selain itu Defisiensi besi juga dapat menyebabkan menurunnya daya tahan tubuh sehingga akan mudah terkena penyakit.

Beberapa penelitian mengungkap jika Pendidikan/penyuluhan gizi dipadukan dengan pemberian suplementasi besi pada anak anemia akanbmemberikan hasil kenaikan kadar hemoglobin yang paling efektif dibandingkan dengan pendidikan gizi saja atau suplementasi sajaselama dua belas minggu (Zulaekah, 2007).

Penelitian ini bertujuan untuk mengetahui pengaruh penyuluhan gizi dan pemberian tablet besi terhadap pengetahuan dan kadar hemoglobin siswi SMAN di Kabupaten Mamuju Provinsi Sulawesi Barat.

\section{METODE}

\section{Jenis Penelitian}

Penelitian ini merupakan jenis penelitian eksperimen semu (Quasi experiment) dengan menggunakan desain non randomized control group pretest - posttest. Pengelompokkan anggota sampel pada kelompok intervensi dan kelompok kontrol dilakukan secara non random.

\section{Populasi dan Sampel}

Populasi penelitian ini adalah seluruh siswi dari dua SMA Negeri yaitu SMAN 2 Mamuju dan SMAN 3 Mamuju. Sampel yaitu 30 siswi SMAN 3 Mamuju sebagai kelompok intervensi dan 30 siswi SMAN 2 Mamuju sebagai kelompok kontrol. Pengambilan sampel menggunakan teknik Purposive sampling dengan kriteria sampel (kriteria inklusi) yaitu: kadar $\mathrm{Hb}<12 \mathrm{~g} / \mathrm{dl}$, siswi bersedia menjadi responden, dan memiliki kemauan untuk mengikuti prosedur sampai selesai dengan menandatangani inform consent. Kriteria eksklusi yaitu; memiliki aktifitas berat, menderita penyakit kronis (seperti diare, TBC dan penyakit lain yang parah).

\section{Variabel dan Pengukuran}

Penyuluhan Gizi dalam penelitian ini adalah pemberian informasi pada siswi tentang Anemia defisiensi Zat Besi, penyuluhan dilakukan secara komprehensif selama sebulan penelitian berlangsung, dengan durasi 60 menit dengan menggunakan metode ceramah dan tanya jawab. Pemberian Tablet Besi merupakan tablet yang mengandung Fero sulfat $100 \mathrm{mg}$ atau setara $30 \mathrm{mg}$ besi elemental dan $0,25 \mathrm{mg}$ asam folat. Diberikan setiap hari selama satu bulan oleh peneliti dibantu enumerator.

Pengetahuan siswi, adalah hasil pretest dan postest pengetahuan tentang gizi pada kelompok intervensi dan kelompok kontrol dikumpulkan secara langsung oleh petugas lapangan dengan berpedoman pada kuesioner dengan 20 pertanyaan dan diberi skor nol untuk setiap jawaban yang salah dan skor satu untuk setiap jawaban yang benar. Selanjutnya dijumlahkan jawaban yang benar dibagi dengan jumlah soal dikali 100 untuk mengetahui skor total yang diperoleh setiap responden.

Kadar Hemoglobin ( $\mathrm{Hb})$ siswi diperoleh berdasarkan pengukuran hemoglobin dengan menggunakan metode pengukuran digital menggunakan Hemoglobinometer. Pemeriksaan dilakukan oleh petugas laboratotium dari Rumah Sakit Umum Daerah Kabupaten Mamuju Provinsi Sulawesi Barat. Pengukuran kadar Hemoglobin dilakukan oleh Laboran yang berkeahlian sebagai Analis 
Kesehatan dan dilakukan pada awal dan akhir penelitian.

\section{Analisis Data}

Analisis data untuk menguji variabel yang diteliti, yaitu dengan Analisis univariat dan analisis Bivariat. Analisis univariat dilakukan untuk menjelaskan atau mendeskripsikan karakteristik tiap variabel yang diteliti dengan menyusun tabel distribusi frekuensi untuk masing-masing variabel. Analisis Bivariat dilakukan untuk mengetahui pengaruh variabel independen terhadap variabel dependen, dilakukan analisis statistik menggunakan uji t berpasangan (Paired Sample $T$ Test) karena data berdistribusi normal dan statistik Wilcoxon Signed Ranks Test karena data tidak berdistribusi normal, dan dilakukan analisis statistik uji Independent T Test karena data terdistribusi normal untuk mengetahui perbedaan pengetahuan pada kelompok intervensi dan kelompok kontrol.

\section{HASIL PENELITIAN \\ Karakteristik Responden}

Jumlah responden pada awal penelitian adalah 88 anak, akan tetapi pada akhir penelitian menjadi 60 anak. Penyusutan jumlah sampel ini terjadi karena berbagai alasan di antaranya adalah anak pindah dari wilayah penelitian, anak menderita sakit sehingga jarang masuk sekolah, anak tidak mau lagi minum suplemen pada pertengahan penelitian atau kepatuhan dan anak tidak mau diambil darahnya pada akhir penelitian. Karakteristik responden dalam penelitian ini mencakup umur, Status Gizi (IMT), dan Pola Makan. Dapat dilihat pada Tabel 1 .

Tabel 1. Distribusi Siswi berdasarkan Status Gizi menurut IMT

\begin{tabular}{|c|c|c|c|c|}
\hline \multirow{2}{*}{ Variabel } & \multicolumn{2}{|c|}{ Kelompok Intervensi } & \multicolumn{2}{|c|}{ Kelompok Kontrol } \\
\hline & $\mathrm{n}=30$ & $\%$ & $\mathrm{n}=30$ & $\%$ \\
\hline \multicolumn{5}{|l|}{ Umur } \\
\hline 15 & 0 & 0 & 3 & 10 \\
\hline 16 & 6 & 20 & 5 & 17 \\
\hline 17 & 16 & 53 & 16 & 53 \\
\hline 18 & 8 & 27 & 5 & 17 \\
\hline 19 & 0 & 0 & 1 & 3 \\
\hline \multicolumn{5}{|l|}{ IMT } \\
\hline Berat Badan Kurang $(<\mathbf{1 8 , 5})$ & 7 & 23 & 5 & 17 \\
\hline Berat Badan Normal $(18,5-22,9)$ & 19 & 64 & 18 & 60 \\
\hline Kelebihan Berat Badan $(\geq 23,0)$ & 4 & 13 & 7 & 23 \\
\hline
\end{tabular}

\section{Pengetahuan Responden}

Nilai rata - rata pengetahuan gizi awal pada kelompok intervensi lebih tinggi yaitu $69,33 \pm 10,1$ dibandingkan kelompok kontrol yaitu $57,17 \pm 14,0$. Begitu juga nilai rata-rata pengetahuan gizi akhir pada kelompok intervensi lebih tinggi yaitu 75,33 dibandingkan dengan kelompok kontrol yaitu 65,00. Hasil uji menunjukkan ada perbedaan bermakna pengetahuan gizi awal dan akhir pada kelompok intervensi $(\mathrm{p}=0,020)$ dan kelompok kontrol $(\mathrm{p}=0,022)$, tetapi Hasil peneltian menunjukkanbahwa tidak ada perbedaan ratarata peningkatan pengetahuan antara kelompok intervensi dan kelompok kontrol $(\mathrm{p}=0,626)$, dapat dilihat pada Tabel 2.

\section{Kadar Hemoglobin Responden}

Hasil uji statistik menunjukkan bahwa terdapat perbedaan kadar $\mathrm{Hb}$ sebelum dan sesudah intervensi pada kelompok intervensi $(\mathrm{p}=0,000)$. Sementara pada kelompok kontrol tidak terdapat perbedaan kadar $\mathrm{Hb}$ sebelum dengan sesudah intervensi $(p=0,384)$. Terdapat perbedaan peningkatan kadar $\mathrm{Hb}$ antara kelompok intervensi dan kelompok kontrol $(\mathrm{p}=0,001)$, dapat dlihat pada Tabel 3 .

\section{PEMBAHASAN}

Penyuluhan gizi merupakan bentuk intervensi yang sifatnya educative, pendekatan tersebut sebagai salah satu upaya dalam mencegah dan mengendalikan anemia gizi secara umum. Penyuluhan gizi secara ekstensif dan persuasive dapat menimbulakn perubahan pengetahuan dan perilaku dalam masyarakat sehingga dapat mengadopsi diversifikasi 
pangan. Selain itu sebagai pemecahan persoalan anemiakarena defisiensi besi dengan membantu masyarakat mengkonsumsi makanan yang kaya dengan zat besi secara teratur, mendorong asupan promotor absorbsi besi vitamin $\mathrm{C}$, dan mencegah konsumsi faktor penghambat yang berlebihan.

Tabel 2. Pengaruh Penyuluhan Gizi terhadap Pengetahuan Pada kelompok Intervensi dan Kelompok Kontrol

\begin{tabular}{|c|c|c|c|c|}
\hline Kelompok & $\begin{array}{c}\text { Median } \\
\text { (Minimum- } \\
\text { Maksimum) }\end{array}$ & Rerata \pm sd & $p^{a}$ & $p^{b}$ \\
\hline \multicolumn{5}{|l|}{ Intervensi $(n=30)$} \\
\hline Pengetahuan Awal & $70,00(40-80)$ & $69,33 \pm 10,1$ & $0,020^{*}$ & \multirow{5}{*}{0,626} \\
\hline Pengetahuan Akhir & $77,50(40-90)$ & $75,33 \pm 12,9$ & & \\
\hline Kontrol $(\mathbf{n}=\mathbf{3 0})$ & & & & \\
\hline Pengetahuan Awal & $57,50(25-80)$ & $57,17 \pm 14,0$ & $0,022^{*}$ & \\
\hline Pengetahuan Akhir & $67,50(30-85)$ & $65,00 \pm 13,8$ & & \\
\hline
\end{tabular}

Tabel 3. Perbedaan Peningkatan Kadar Haemoglobin Sebelum dan Sesudah Intervensi antara Kelompok Intervensi dan Kelompok Kontrol

\begin{tabular}{ccccc}
\hline Kelompok & $\begin{array}{c}\text { SebelumIntervensi } \\
\text { Rata-rata } \pm \text { sd }\end{array}$ & $\begin{array}{c}\text { Sesudah Intervensi } \\
\text { Rata-rata } \pm \text { sd }\end{array}$ & $\begin{array}{c}\text { Rata-Rata } \\
\text { Peningkatan }\end{array}$ & $p^{a}$ \\
\hline Intervensi $(\mathrm{n}=30)$ & $9,11 \pm 1,05$ & $10,04 \pm 1,10$ & 0,93 & \\
Kontrol $(\mathrm{n}=30)$ & $9,53 \pm 1,31$ & $9,25 \pm 1,41$ & $-0,27$ & $0,001^{*}$ \\
\hline
\end{tabular}

${ }^{\mathrm{a}}$ Uji Independent $\mathrm{T}$ Test

p $<0,05$

Pengetahuan responden dapat dilihat dari kemampuannya dalam menjawab dengan benar pertanyaan-pertanyaan mengenai defenisi, gejala, tanda, makanan penghambat dan pelancar zat besi, penyebab, akibat, upaya pencegahan dan pengobatan anemia. Hasil penelitian ini menunjukkan bahwa terdapat pengaruh penyuluhan terhadap peningkatan pengetahuan siswi setelah dilakukan intervensi penyuluhan Gizi selama empat minggu. Seseorang yang memiliki tingkat pengetahuan yang baik berpengaruh terhadap cara pemilihan jenis makanan demi memenuhi kebutuhan hidupnya. Beberapa penelitian tentang pendidikan/penyuluhan gizi terutama tentang zat besi dan kadar hemoglobin menunjukkan bahwa pendidikan gizi memberikan pengaruh yang positif terhadap pengetahuan gizi besi dan kadar hemoglobin. Hasil penelitian ini sejalan dengan hasil penelitian Yusoff yang menunjukkan bahwa peningkatan tingkat kesadaran perempuan berkaitan dengan pengetahuan gizi dan anemia setelah intervensi pendidikan gizi di lingkungan sekolah (Yussof, Daud and Ahmad, 2013).

Hasil Penelitian menunjukkan bahwa tidak ada perbedaan rata-rata Peningkatan Pengetahuan antara kelompok intervensi dan kelompok kontrol. Hal ini terjadi karena sebelum intervensi tingkat pengetahuan pada kelompok intervensi memang sudah tinggi dibandingkan dengan kelompok kontrol. Di samping itu intensitas pemberian penyuluan tidak sama yang dilakukan pada penelitian lain yang rata-rata 2 kali sebulan selama 3 bulan.

Pada umumnya sampel penelitian tergolong anemia ringan, sedang dan berat dengan kadar hemoglobin minimal $7 \mathrm{gr} / \mathrm{dL}$ 
maksimal $11 \mathrm{~g} / \mathrm{dL}$ dan rata-rata $\pm 10,04 \mathrm{~g} / \mathrm{dL}$ pada saat dilakukan pemeriksaan awal. Hasil penelitian menunjukkan bahwa terdapat pengaruh penyuluhan dan pemberian tablet besi terhadap peningkatan kadar $\mathrm{Hb}$ pada kelompok intervensi $(\mathrm{p}=0,000)$. Pengaruh penyuluhan dan pemberian tablet besi terhadap peningkatan kadar $\mathrm{Hb}$ pada kelompok intervensi sejalan dengan penelitian Sarwa (2003) yang menunjukkan bahwa intensifikasi penyuluhan gizi dalam pemberian tablet besi merupakan determinan terhadap pencapaian nilai hemoglobin pada ibu.

Rata-rata peningkatan kadar $\mathrm{Hb}$ siswi pada kelompok intervensi adalah 0,93 g/dl, sedangkan pada kelompok kontrol justru mengalami penurunan yaitu rata-rata $-0,27 \mathrm{~g} / \mathrm{dl}$. Kemudian dilakukan uji statistik untuk melihat perbedaan peningkatan kadar $\mathrm{Hb}$ sebelum dan sesudah intervensi antara kelompok intervensi dan kelompok kontrol maka hasil penelitian menunjukkan adanya perbedaan peningkatan yang signifikan $(p=0,001)$. Pemberian tablet besi pada kelompok remaja usia Sekolah Menengah Atas, yang mendekati masa perkawinannya, akan berguna untuk mempersiapkan masa kehamilannya selain bermanfaat untuk meningkatkan prestasi belajar mereka.

Hasil Penelitian ini sejalan dengan hasil penelitian yang dilakukan oleh Penelitian Zulaekha (2007) menunjukkan bahwa pemberian pendidikan gizi yang dipadukan dengan suplementasi besi secara statistik terjadi perubahan yang bermakna terhadap perubahan kadarhemoglobin anak yang anemia sebelum dansesudah intervensi,begitupun dengan hasil penelitian Ahmed et all (2005) menunjukkan bahwa Pemberian zat besi memiliki pengaruh yang signifikan terhadap peningkatan kadar $\mathrm{Hb}$ pada remaja putri di sekolah.

\section{KESIMPULAN}

Hasil penelitian ini menunjukkan tidak terdapat perbedaan peningkatan pengetahuan setelah penyuluhan, sedangkan padapemberian tablet besi terdapatpeningkatan kadar hemoglobin $(\mathrm{Hb})$.

\section{UCAPAN TERIMAKASIH}

Terima kasih disampaikan kepada Direktur Poltekkes Kemenkes Mamuju atas pemberian ijin dan pembiayaan terhadap penelitian ini, kepada Kepala Sekolah SMA Negeri 2 Mamuju dan Kepala Sekolah SMA Negeri 3 Mamuju atas pemberian ijin dan bantuannya selama penelitian, serta ucapan terimakasih khususnya kepada siswi kedua sekolah tersebut yang telah bersedia sebagai responden dan mengikuti penelitian sampai selesai.

\section{DAFTAR PUSTAKA}

Michael J.G. (2008). Gizi Kesehatan Masyarakat, EGC. Jakarta, 276-278.

Ahmed et.all. (2005). Efficacy of twice-weekly multiple micronutrient supplementation for improving the hemoglobin and micronutrient status of anemic adolescent schoolgirls in Bangladesh. American Journal of Clinical Nutritiona, 82(4):829-35.

Sindhu S, Mangala S, Sherry B. (2013). Efficacy Of Moringa Oleifera In Treating Iron Deficiency Anemia In Women Of Reproductive Age Group. International Journal Of Phytotherapy Research, 3(4).

Laporan Nasional Riset Kesehatan Dasar. (2013). Jakarta: Badan Penelitian dan Pengembangan Kesehatan Departemen Kesehatan RI. http://www. depkes.go.id/resources/download/general /Riskesda2013.pdf.

Ngatimin dan Rahmawati. (2009). Prevalensi dan Tingkat Keparahan Anemia dan Iron Deficiency pada Remaja Putri di Daerah Endemik Malaria Kabupaten Maтuju Propinsi Sulawesi Barat. http:// repository.unhas.ac.id/handle/123456789 13759 .

Arisman MB. (2008). Gizi dalam Daur Kehidupan. Buku Kedokteran. Jakarta, 65-66.

Abbas, dkk. (2005). Asupan Zat Besi Pada Remaja Putri Usia 10-14 Tahun di Pulau Barrang Lompo Makkasar Tahun 2003. Media Kesehatan Masyarakat Indonesia, 1(1).

Survei Demografi Dan Kesehatan Reproduksi Remaja. (2012). Jakarta: Badan Pusat Statistik. http://chnrl.org/pelatihandemografi/SDKI-2012.pdf.

Zulaekah. (2007). Efek Suplementasi Besi, Vitamin C dan Pendidikan Gizi Terhadap Perubahan Kadar Hemoglobin Anak Sekolah Dasar Yang Anemia Di Kecamatan Kartasura Kabupaten Sukoharjo. Thesis Program Pascasarjana Universitas Diponegoro Semarang.

Yussof, Daud and Ahmad. (2013). Effectiveness of Nutrition Education vs. Non-Nutrition 
Educa-tion Intervention in Improving Awareness Pertaining Iron Defi-ciency among Anemic Adolescents. Iranian $\mathrm{J}$ Publ Health, 42(5); 467-71.

Sajjan, Kasturiba, Naik, and Bharati. (2011). Impact of child to child nutrition education intervention on nutrition knowledge scores and hemoglobinstatus of rural adolescent girls. Karnataka Journal. Agric. Sci, 24 (4):513-5.

Sarwa. (2003). Pengaruh Intensifikasi Penyuluhan Gizi dalam Pemberian Tablet Besi pada Ibu Hamil terhadap Kepatuhan Mengkonsumsi dan Pencapaian nilai Hemoglobin Harapan. Tesis. Universitas Diponegoro Semarang. 